\title{
Implementasi Kebijakan Pemungutan Pajak Hotel Kategori Rumah Kos di Kecamatan Tondano Selatan
}

\author{
$1^{\text {st }}$ Devie S. R. Siwij \\ FIS UNIMA \\ Prodi ilmu administrasi negara \\ Tondano, Indonesia \\ dsiwij@gmail.com \\ $2^{\text {nd }}$ Jetty E. H. Mokat \\ FIS UNIMA \\ Prodi ilmu administrasi negara \\ Tondano, Indonesia \\ jettymokat@gmail.com \\ $3^{\text {rd }}$ Cecilia C. Pilomali \\ FIS UNIMA \\ Prodi ilmu administrasi negara \\ Tondano, Indonesia \\ ceciliapilomali@gmail.com
}

Abstrak- Penelitian ini bertujuan untuk mengetahui implementasi kebijakan Pemungutan Pajak Hotel Kategori Rumah Kos di Kecamatan Tondano Selatan. Pendekatan yang digunakan adalah kualitatif fenomenologis. Teknik pengumpulan data adalah: (a) observasi terhadap rumah kos, (b) wawancara kepada pemilik rumah kost, kepala lingkungan, lurah dan implementer, (c) dokumentasi tentang perizinan rumah kos dan izin mendirikan bangunan. Hasil penelitian ini menunjukkan bahwa kebijakan Pemungutan Pajak Hotel Kategori Rumah Kos di Kecamatan Tondano Selatan belum dilaksanakan secara maksimal karena: (a) implementasi kebijakan belum diimplementasikan sesuai standard dan sasaran kebijakan, (b) implementer belum sepenuhnya berkomitmen untuk mengimplementasikan standard dan sasaran kebijakan, (c) belum dilakukan sosialisasi secara utuh kepada pemilik rumah kos, (d) kondisi sosial budaya masyarakat belum siap menunjang implementasi kebijakan. Untuk itu disarankan sebaiknya: (a) implementasi kebijakan diimplementasikan sesuai standard dan sasaran kebijakan, (b) implementer berkomitmen untuk mengimplementasikan standard dan sasaran kebijakan, (c) dilakukan sosialisasi secara utuh kepada pemilik rumah kos, (d) kondisi sosial budaya masyarakat dipersiapkan untuk menunjang implementasi kebijakan.

Kata kunci : Implementasi Kebijakan, Pemungutan Pajak Hotel Kategori Rumah Kos, Tondano Selatan, Sulawesi Utara. 


\section{PENDAHULUAN}

Pajak daerah merupakan salah satu sumber pendapatan daerah yang berguna untuk membiayai pelaksanaan pemerintahan daerah. Undang-Undang Nomor 28 Tahun 2009 Tentang Pajak dan Retribusi Daerah Pasal 1 Ayat 10 yang berbunyi "Pajak daerah adalah kontribusi wajib kepada daerah yang terutang oleh orang pribadi atau badan yang bersifat memaksa berdasarkan Undang-Undang, dengan tidak mendapatkan imbalan secara langsung dan digunakan untuk keperluan daerah bagi sebesar-besarnya kemakmuran rakyat" [1]. Dengan adanya pajak daerah ini, dimaksudkan untuk lebih memajukan pelayanan kepada masyarakat dan kemandirian daerah.

Rumah kos masuk dalam bagian dari pajak Hotel yang berpotensi memberikan pemasukan pada PAD di Kabupaten Minahasa khususnya di Kecamatan Tondano Selatan. Karena Tondano Selatan merupakan satu-satunya kecamtan di kabupaten Minahasa yang memiliki Perguruan Tinggi Negeri (PTN). Universitas Negeri Manado merupakan Perguruan Tinggi Negeri yang termasuk dalam wilayah Administratif Tondano Selatan.

Seiring dengan banyaknya mahasiswa pendatang yang berasal dari luar Kecamatan Tondano Selatan, memungkinan usaha rumah kos dinilai sangat berpotensi besar dan menguntungkan. Dengan adanya pajak hotel ketegori rumah kos selain untuk meningkatkan pelayanan kepada masyarakat dan kemandirian daerah pambangunan daerah, juga dimaksudkan agar para pendatang memiliki kontribusi dalam pembangunan daerah yang dalam hal ini Kabupaten Minahasa. Namun dalam pelaksanaan pemungutan pajak hotel ketegori rumah kos yang dilakukan oleh BPP-RD di Kecamatan Tondano Selatan masih belum maksimal, dimana masih banyak diperoleh pemilik usaha rumah kos yang tidak membayar pajak tersebut. Berdasarkan informasi yang diberikan oleh BPP-RD Kabupaten Minahasa hanya 4 (empat) dari 187 (seratus delapan puluh tujuh) pemilik usaha rumah kos yang masih aktif memberikan kewajibannya. Selain itu terdapat juga target dan realisasi pajak hotel kategori rumah kos yang mengalami penurunan.

Dengan adanya masalah yang ditemui tersebut, peneliti tertarik untuk mengadakan penelitian mengenai "Implementasi Kebijakan Pemungutan Pajak Hotel Kategori Rumah Kos Di Kecamatan Tondano Selatan", dengan tujuan untuk mengetahui Implementasi Kebijakan Pemungutan Pajak Hotel Kategori Rumah Kos di Kecamatan Tondano Selatan dan mengetahui faktor-faktor yang mempengaruhi implementasi kebijakan tersebut. 


\section{METODE PENELITIAN}

Pendekatan penelitian ini menggunakan pendekatan kualitatif fenomenologis, Pendekatan yang digunakan adalah kualitatif fenomenologis. Tehnik pengumpulan data adalah: (a) observasi terhadap rumah kos, (b) wawancara kepada pemilik rumah kost, kepala lingkungan, lurah dan implementer, (c) dokumentasi tentang perizinan rumah kos dan izin mendirikan bangunandi Kecamatan Tondano Selatan .

\section{HASIL DAN PEMBAHASAN}

\section{Penghimpunan Data Objek dan Subjek Pajak}

Penghimpunan data objek dan subjek pajak, diawali dengan pelaporan para pemilik usaha rumah kos kepada BPP-RD, kemudian BPP-RD daftarkan dan akan dihimpun sebagai data objek dan subjek pajak.

Namun penghimpungan data objek dan subjek pajak yang terjadi dilapangan belum sesuai dengan prosedur yang ada, dimana yang seharusnya para pemilik usaha yang datang langsung untuk melaporkan dirinya sebagai WP ke BPP-RD terbalik menjadi BPP-RD yang turun lapangan untuk mendata para WP. Hal ini dilakukan BPP-RD agar dapat menjaring para pemilik usaha rumah kos dalam rangka meningkatkan kepatuhan WP.
Berbagai alasan para pemilik usaha rumah kos di Kecamatan Tondano Selatan yang tidak mendaftarkan usahanya sebagai objek pajak, mulai dari pajak yang dikenakan terlalu tinggi, masih adanya tunggakan di bank, pajak ini dipandang hanya merugikan, pendapatan yang diperoleh tidak sesuai dengan yang diharapkan, dan yang paling umum adalah mahasiswa yang sering menunggak. Sehingga terlihat disini kurangnya kesadaran membayar pajak dari para WP karena WP cenderung menghindarkan diri dari pajak.

\section{Komitmen}

Sanksi pajak hotel kategori rumah kos di Kecamatan Tondano Selatan diatur dengan Peraturan Bupati Nomor 6 Tahun 2011 tentang Sistem, Prosedur, dan Sanksi Pemungutan Pajak Daerah Kabupaten Minahasa [2].

Namun sanksi yang peneliti peroleh dilapangan tidak dilaksanakan sebagaimana mestinya, dimana didapati bahwa pemerintah tidak pernah memberikan surat teguran kepada WP, sehingga para WP bisa seenaknya tidak bayar pajak karena tidak ada efek jerah yang dirasakannya. Dari hasil penelitian tersebut dapat disimpulkan bahwa Badan Pengelola Pajak dan Retribusi Daerah Kabupaten Minahasa tidak tegas dalam menyikapi permasalahan tersebut. 

implementasi kebijakan menurut Hogwood dan

\section{Standar Dan Sasaran Kebijakan}

Diperlukan adanya pengawasan yang efektif sehingga tidak terjadi penyelewengan aturan serta meminimalisir terjadi masalah baru. Dengan demikian pengawasan haruslah dilakukan pada saat kegiatan berlangsung hingga kegiatan selesai, sehingga terciptanya suatu kondisi yang mendukung kelancaran dan ketepatan dalam pelaksanaan kebijakan.

Berdasarkan hasil penelitian yang diperoleh, dapat dikatakan bahwa pengewasan yang dilakukan oleh BPP-RD masih kurang efektif, karena untuk proses pendataan rumah kos yang masih aktif dan tidak aktif hanya berdasarkan kedatangan WP untuk penyetoran pajak, jadi ketika WP tidak lagi menyetor maka secara langsung WP dianggap tidak aktif lagi. Dan pengecekannya pun tidak dilakukan per bulan atau pada saat WP tidak menyetor lagi, sehingga sangat mendukung WP untuk tidak membayar pajak. Hal ini membuka peluang besar bagi para pemilik usaha rumah kos baru untuk tidak membayar pajak.

Adapun faktor-faktor yang mempengaruhi implementasi kebijakan ini adalah sebagai berikut.

\section{Komunikasi dan Koordinasi}

Komunikasi dan koordinasi juga perlu diperhatikan karena tanpa adanya komunikasi dan koordinasi yang sempuran suatu kebijkan pastinya tidak akan berjalan dengan semestinya, seperti salah satu dari 10 syarat yang dibutuhkan dalam

Gun. Komunikasi dan koordinasi antara BPP-RD dengan kelurahan tidak ada dimana para lurah maupun sekretaris lurah tidak mengetahui peraturan apa yang melandasi pemungutan pajak hotel kategori rumah kos serta untuk pemahamannya pun masih minim. Padahal dengan adanya komunikasi dan koordinasi yang baik, memungkinkan proses implementasi berjalan dengan baik adanya.

\section{Kondisi Ekonomi dan Sosial}

Kondisi ekonomi, sosial, dan politik yang sejalan dengan salah satu variabel dari model implementasi yang dikemukakan oleh Donald Van Meter dan Carl Van Horn (Agustino 2008:141-144) [3]. Untuk kondisi politik dalam hal ini tidak mempunyai pengaruh. Kondisi ekonomi dan sosial yang peneliti peroleh dilapangan masih belum stabil. Dimana sebagian besar kondisi ekonomi para pemilik usaha rumah kos masih pada tahap menengah kebawah sehingga sulit bagi mereka untuk membayar pajak menurut mereka pemerintah seharusnya tidak hanya melihat berdasarkan jumlah kamar yang ada, tapi juga berdasarkan pelayanan serta fasilitas yang ada. Adapun kondisi sosial lebih bersifat membantu sehingga tidak terlalu menekan penyewa yang belum bisa membayar tunggakan, kebanyakan usaha rumah kos yang didirikan bersifat semi sosial. 


\section{PENUTUP}

Hasil penelitian ini menunjukkan bahwa implementasi kebijakan pemungutan pajak hotel kategori rumah kos di Kecamatan Tondano Selatan belum maksimal dikarenakan Hasil penelitian ini menunjukkan bahwa kebijakan Pemungutan Pajak Hotel Kategori Rumah Kos di Kecamatan Tondano Selatan belum dilaksanakan secara maksimal karena: (a) implementasi kebijakan belum diimplementasikan sesuai standard dan sasaran kebijakan, (b) implementer belum sepenuhnya berkomitmen untuk mengimplementasikan standard dan sasaran kebijakan, (c) belum dilakukan sosialisasi secara utuh kepada pemilik rumah kos, (d). kondisi sosial budaya masyarakat belum siap menunjang implementasi kebijakan. Untuk itu disarankan sebaiknya: (a) implementasi kebijakan diimplementasikan sesuai standard dan sasaran kebijakan, (b) implementer berkomitmen untuk mengimplementasikan standard dan sasaran kebijakan, (c) dilakukan sosialisasi secara utuh kepada pemilik rumah kos, (d). kondisi sosial budaya masyarakat dipersiapkan untuk menunjang implementasi kebijakan. http://ejournal.unima.ac.id/index.php/administro UCAPAN TERIMA KASIH

Terimakasih disampaikan kepada semua pihak yang boleh membanti dalam pelaksaan penelitian sehingga artikel ini dapat diselesaikan. 
Jurnal Kajian Kebijakan dan Ilmu Adminiatrasi Negara (JURNAL ADMINISTRO) Vol 1 No. 2 Desember 2019

P ISSN: 2714 - 6413 E ISSN: $2714-6421$

http://ejournal.unima.ac.id/index.php/administro

\section{REFERENSI}

[1] Undang-Undang Nomor 28 Tahun 2009

Tentang Pajak Daerah dan Retribusi Daerah

[2] Peraturan Bupati Minahasa Nomor 6 Tahun

2011 tentang Sistem, Prosedur, dan Sanksi

Pemungutan Pajak Daerah Kebupaten

Minahasa

[3] Agustino Leo. 2008. Dasar-Dasar Kebijakan

Publik. Alfabeta : Bandung 